Columbia Law School

Scholarship Archive

2016

\title{
Corporate Governance Changes as a Signal: Contextualizing the Performance Link
}

\author{
Merritt B. Fox \\ Columbia Law School, mfox1@law.columbia.edu \\ Ronald J. Gilson \\ Columbia Law School, rgilson@law.columbia.edu \\ Darius Palia \\ dpalia@rci.rutgers.edu
}

Follow this and additional works at: https://scholarship.law.columbia.edu/faculty_scholarship

Part of the Business Organizations Law Commons, European Law Commons, and the Law and Economics Commons

\section{Recommended Citation}

Merritt B. Fox, Ronald J. Gilson \& Darius Palia, Corporate Governance Changes as a Signal:

Contextualizing the Performance Link, EUROPEAN CORPORATE GovernANCE INSTITUTE (ECGI) LAW WoRKING Paper No. 323/2016; Stanford LaW \& ECONOMics Olin Working PaPer No. 496 (2016).

Available at: https://scholarship.law.columbia.edu/faculty_scholarship/1989

This Working Paper is brought to you for free and open access by the Faculty Publications at Scholarship Archive. It has been accepted for inclusion in Faculty Scholarship by an authorized administrator of Scholarship Archive. For more information, please contact scholarshiparchive@law.columbia.edu. 


\title{
Corporate Governance Changes As a Signal: Contextualizing the Performance Link
}

\author{
Merritt B. Fox, ${ }^{*}$ Ronald J. Gilson, ${ }^{* *}$ and Darius Palia ${ }^{* * *}$
}

November 2016

Promoting "good" corporate governance has become a global industry. Large international organizations like the OECD have adopted corporate governance codes of best practice. ${ }^{1}$ Major institutional investors like the Norwegian Government Fund Global (a sovereign wealth fund), the California Public Employees Retirement System and BlackRock have similar codes to guide their choices as to where to invest and how to vote the shares in their portfolio. ${ }^{2}$

Corporate governance concerns have also animated regulatory change. They were at the center of the conditions that the IMF imposed on financial assistance to countries after the East Asian

\footnotetext{
* Michael E. Patterson Professor of Law, NASDAQ Professor for the Law and Economics of Capital Markets, Columbia Law School;

** Marc \& Eva Stern Professor of Law \& Business, Columbia Law School, Charles J. Meyers Professor of Law \& Business emeritus, Stanford Law School and, and European Corporate Governance Institute; and

**** Thomas A. Renyi Chair in Banking, Rutgers Business School, and Senior Fellow, Center on Contract and Economic Organization, Columbia Law School, respectively. We thank participants at Columbia Law School's Blue Sky Workshop and the Anton Phillips/Leiden University Conference on Institutional Investors and the Question of Shareholder-Oriented Governance, as well as Marcel Kahan, Michael Klausner and Joseph McCahery for helpful comments. We also thank Martijn Cremers for providing the governance data. All errors remain our responsibility.

1 See, e.g., G20/OECD Principles of Corporate Governance (2015), available at http://www.oecdilibrary.org/docserver/download/2615021e.pdf; Swiss Code of Best Practice for Corporate Governance (2014), available at http://www.ecgi.org/codes/documents/swiss_code_26sep2014_en.pdf.

${ }^{2}$ See California Public Employment Retirement System, "CalPERS Global Principles of Accountable Corporate Governance," (Nov. 14, 2011), http://www.calpers-governance.org/principles/home accessed 11/18/13; BlackRock, Global Corporate Governance \& Engagement Principles (June 2014), available at http://www.blackrock.com/corporate/en-ca/literature/fact-sheet/blk-responsible-investment-1engprinciples-global122011.pdf.
} 
financial crisis. ${ }^{3}$ Country specific codes, like the Cadbury Code in the United Kingdom, have proliferated. ${ }^{4}$ In the United States, both the Sarbanes-Oxley legislation following the Millennium accounting scandals and the Dodd-Frank legislation following the "Great Recession" sought, among other things, to improve the corporate governance practices of the companies they cover. ${ }^{5}$ In turn, Delaware courts over the last 25 years have devoted a great deal of attention to creating and explicating the governance content of Delaware corporate law. ${ }^{7}$

The premise that underlies most of these efforts is that "good" corporate governance provisions increase firm value. However, nagging concerns remain as to whether they in fact do so. These concerns suggest two central questions: which governance provisions can actually increase firm value and under what circumstances do they do so? Legal and finance academics have both spearheaded the concerns about corporate governance and followed in its wake. A large literature has arisen in response, seeking to test empirically the link between governance and performance. ${ }^{8}$

Some of this work has yielded positive results, suggesting a relationship between particular provisions, or sets of provisions, and firm value. The studies so far, however, typically only

\footnotetext{
${ }^{3}$ See, e.g., John M. Broder, "Asia Pacific Talks Vow Tough Action on Economic Crisis", The New York Times, 11/26/97, at A1; Timothy Lane et al., IMF-Supported Programs in Indonesia, Korea, and Thailand: A Preliminary Assessment, pp. $72-3$ (International Monetary Fund, Occasional Paper No. 178, 1999).

${ }^{4}$ Various country codes are available at European Corporate Governance Institute web site. See Index of Codes, European Corporate Governance Institute, http://www.ecgi.org/codes/all_codes.php (last visited November 11, 2016). 5 Sarbanes-Oxley, for example, aims to improve auditor , see 15 U.S. C. $\S \S 201-209$ (2012); promote the independence of audit committees of listed corporations, see id. $\S 78 \mathrm{j}-1$; and increase corporate managers' responsibility for financial disclosures, see id. $§ 7241$. Dodd-Frank implemented a host of governing reforms as well, focusing in particular on executive compensation structures. See Dodd-Frank Wall Street Reform and Consumer Protection Act, Pub. L. No. 111-203, §§ 951-957, 124 Stat. 1376, 1899-1907

${ }^{7}$ See, e.g., Jack B. Jacobs, Fifty Years of Corporate Law Evolution: A Delaware Judge's Retrospective, 5 Harv. Bus. L. Rev. 141 (2015).

${ }^{8}$ This literature is discussed in Part III infra.
} 
measure the average impact on firm value of a company's score on an index of one or a set of such provisions across a large number of corporations over a considerable period of time. Many of these studies have been challenged based on theoretical grounds. The claim is that the governance provisions that make up the indices either cannot, in fact, have an impact on corporate on corporate performance or that, like the poison pill, can be adopted quickly and easily when management feels the need and so their presence or absence at a point in time has no consequence. This Article is a first contribution to a much needed next stage of research: a more focused inquiry into the particular circumstances in which the observed empirical link between governance and performance can be supported in theory.

Specifically, we empirically test the hypothesis that corporate governance provisions can serve as credible signals of the quality of a firm's management and that these signals can matter more in times when managerial quality is more difficult to observe directly. Taking advantage of a natural experiment when uncertainty concerning management quality was widely reported to be especially high - the period of the accounting scandals disclosed following the turn of the century, we report evidence supporting a management quality-based signaling hypotheses.

Our analysis proceeds as follows. Part I sets out the existing pattern of empirical corporate governance research, focusing on corporate governance index studies reporting positive results linking better governance and better corporate performance. It also describes important recent criticisms of these index studies: that a correct understanding of the institutional context is inconsistent with a causal connection between many of the elements of the indices and good performance. Part I then sets out a signaling hypothesis that does link changes that improve governance index ratings to better corporate performance as measured by Tobin's Q. 
Part II explains how the governance indices are created, describes Tobin's Q, the typical measure of the firm's success at creating value, and develops three hypotheses that link good corporate governance to good corporate performance. Not surprisingly, two of these three theories focus on improving firm management. The third, however, focuses on improving the market's information about the quality of existing firm management. This third theory forms the basis for our signaling hypothesis and the empirical results reported in this article.

Part III reports our empirical tests of the signaling hypothesis. It first describes the Millennial accounting scandals - Enron, WorldCom and others - and the capital market's reaction to them, and then sets forth our central empirical finding: that a change in a company's governance index score during the period when the accounting scandals were being reported resulted in a much larger change in measures of corporate performance then did governance changes in the years surrounding the accounting scandal period. Part IV concludes.

\section{The Existing State of Empirical Corporate Governance Research}

An important element of the existing empirical literature examining the link between corporate governance and performance consists tests the effect on firm value of a governance structure that warrants a good rating on an index purporting to measure the overall quality of a firm's corporate governance. These tests have shown positive results but have been subject to some cogent criticisms. This state of affairs suggests that the positive results are the product of a more complicated story than the one employed to design the index. Our analysis here is an early effort to explore this more complicated story. 


\section{A. Index Studies}

In index-based studies, the author of the index posits a list of corporate governance provisions whose presence or absence she believes helps the firm create value. For each provision, a firm is awarded a score of zero if the firm's status with respect to the provision is what the author believes will contribute to firm value, and a score of one if she believes the firm's status will erode firm value. A firm's score with respect to each provision is summed to obtain its overall corporate governance rating. The lower a firm's rating, the better the index suggests is its overall corporate governance. The two most popular indices constructed in this way are the "G index" and the "E index." 12 These index-based studies are our focus here.

The claimed link between these indices and corporate performance has been empirically tested as follows. First, the index score of a large number of firms are calculated over a number of years , creating a few thousand firm-year observations. A performance metric such as Tobin's Q is then used to determine whether firms with better governance scores created more value with the capital that investors have provided them than have firms with poorer scores. ${ }^{13}$ A number of such index studies of U.S. firms show a positive relation between a good governance index score and value creation as measured by Tobin's Q. ${ }^{14}$

\footnotetext{
${ }^{12}$ The G index was originally designed for use in the study reported in Paul Gompers et al., Corporate Governance and Equity Prices, 118 Q.J. ECON. 107 (2003). The E index was originally designed for use in the study reported in Lucian Bebchuk, Alma Cohen \& Allen Ferrell, What Matters in Corporate Governance, 22 REV. FIN. STUD. 783 (2009). These studies are discussed in more detail in Part III.C infra.

${ }^{13}$ Tobin's Q involves the ratio of the market value of the firm (a measure of value) over the book value of the firm (a measure of the amount of capital that management was provided to deploy and utilize in order to create this value). Tobin's Q will be discussed in more detail in Part II.B infra.

${ }^{14}$ These results are discussed in more detail in Part III.C infra.
} 


\section{B. Critiques of Index Studies}

Index-based studies showing a positive relationship between a good $\mathrm{G}$ or $\mathrm{E}$ index rating and greater firm value have been subject to considerable criticism challenging the link between a good governance index rating and greater value creation from invested capital. The thrust of these critiques is that the actual institutional context in which particular governance provision operates shows that in practice their presence or absence should have no significant effect on firm value. ${ }^{15}$ Most notably, these critics argue that because a firm can adopt a poison pill through a board resolution very quickly, all firms have a "shadow" pill and so that the formal adoption of a "real" pill can have no consequence. ${ }^{16}$

The criticisms that the indices misunderstand the institutional context in which the governance provisions operate appear well taken, but they do not explain why the challenged studies nevertheless arrive at their positive results. Thus, while the critiques do not necessarily invalidate the conclusion of the challenged studies that firms with good ratings on average create more value, they do suggest the results of the challenged studies must be due to a more complicated story than the governance theories used to construct the indices. ${ }^{17}$ That a more complicated story may be at

\footnotetext{
${ }^{15}$ See, e.g., Catan \& Kahan, supra note 11. Michael Klausner, Fact and Fiction in Corporate Law and Governance, 65 StAn. L. ReV 1325 (2013); Klausner, [Oxford chapter]. Black et.al., What Matters and for Which Firms for Corporate Governance in Emerging Markets?: Evidence from Brazil (and other BRIK Countries), 18 J. CORP. FIN. 934 (2012), argue that the impact of governance elements is context specific, and so can be expected to have different results in different countries. This is a particularized version of the more general critique that tests of the impact of governance elements too often lack an institutional grounding for the tested hypotheses. Critics have also found inaccuracies in the coding of the corporations sampled in each study, which means that some of the sampled corporations that are subject to a particular provision are scored as not being so and vice-versa). See David F. Larcker, Peter C. Reiss \& Youfei Xiao, Corporate Governance Data and Measures Revisited (Rock Center for Corporate Governance, Stanford University, Working Paper No. 213, 2015), available at http://ssrn.com/abstract=2694802. ${ }^{16}$ [Coates].

${ }^{17}$ Michael Klausner is a prime exemplar the critics. Klausner does see a plausible causal story linking lower firm value due to entrenched management with one item that is scored in both the $G$ and $E$ indexes: the presence of a staggered board. A board is staggered when one third of its members is elected annually for a three-year term. A staggered board, when combined with a poison pill, can effectively block a hostile takeover for two years. Klausner,
} 
work should not be surprising. Careful observers of the corporate world would find it highly likely

that, rather than a single link between the specified corporate governance provisions and

performance, a range of linkages are possible whose direction and intensity depend centrally on

the particular context in which a firm is operating. From this perspective, the impact of governance

supra note 15, at 1352-53. His review of the event study literature on staggered boards suggests to him that this causal story is in fact correct. Id. at 1554-55. Klausner does not, however, see a plausible causal story linking lower firm value to the presence of a poison pill, another item scored in both the $\mathrm{G}$ and $\mathrm{E}$ indexes. He argues that since a board can adopt a pill at a moment's notice, management effectively always has the takeover protection from a pill whether or not it is in place prior to it being needed. Id. at 1350-52. He argues as well that the combination of a staggered board and the ever present availability of a poison pill dominate all the other takeover defense mechanisms scored by the $\mathrm{G}$ or E index, rendering these others irrelevant. Yet, a firm with both a staggered board and one or more of these governance features that putatively entrench management - the absence of the ability of shareholders to take action by written consent and the absence of a provision for a special shareholders meeting, and supermajority requirements for shareholder votes on by amendments, charter amendments and mergers -- will get a higher (i.e., worse) governance score than a firm with just a staggered board. Finally, Klausner argues that a number of other scored items, for example director indemnification provisions and protection for outside directors from liability for money damages for a violation of a duty of care, are unrelated to the ability of management to entrench itself and are viewed by many as promoting good governance. Yet these also lead to a higher score. Id. at 1367.

Klausner makes important points: with a better understanding the institutional realities, the indices could have been constructed with considerably more subtlety so as to frame a better hypothesis between governance characteristics and firm performance. Still, there is a plausible story that on average firms that score better (i.e., lower) on the $\mathrm{G}$ or $\mathrm{E}$ indexes will create more value. To start, the presence of a staggered board is scored by both indexes and, as Klausner himself relates, there are strong reasons, both theoretically and empirically, to believe that a staggered board will lead to lower-value-creation managerial behavior. As for governance features scored by one or both of the indexes that become irrelevant in the presence of a staggered board, they may nonetheless be of consequence for the approximately $40 \%$ of firms that do not have a staggered board. Moreover, the firms that do have staggered boards, in many cases do not have these other governance features ( $80 \%$ do not limit have supermajority provisions, a majority do not limit shareholder action by written consent, and a majority do not prohibit special meetings), perhaps in each case for the very reason that they are irrelevant. The absence of a poison pill may become relevant in a case where a firm had a pill in place and then management removed it, perhaps to improve its governance image. To thereafter reinstate the pill at the time of a hostile takeover fight would tarnish management and hurt its chances in the proxy fight against the potential hostile acquirer. There is empirical evidence consistent with this conjecture. Vicente Cuñat, Mireia Giné and Maria Guadalupe report that approval of a precatory shareholder proposal to remove an antitakeover proposal listed in the $\mathrm{G}$ index results in an increase in the cumulative probability that the firm will be the target of a successful takeover within 5 years after the vote of 12 to 14\%, with a sample composed of all shareholder-sponsored proposals to remove an antitakeover provision voted on in annual meetings of S\&P 1500 firms between 1994 and 2013 (2809 proposals in 929 different firms). Vicente Cuñat, Mireia Giné and Maria Guadalupe, Price and Probability: Decomposing the Takeover Effects of Anti-Takeover Proposals (working paper, January 27, 2015). Finally, as for the $\mathrm{G}$ index items that are unrelated to entrenching incumbent management, the quality of governance can, at least at the level of theory, be improved by means other than reducing managerial entrenchment, for example by affecting the tradeoff between attracting the best officers and directors, which may aided by indemnification and protection exposure to money damage suits for fiduciary duty violations, and the deterrent effect of facing such damage actions without such indemnification or protection. The absence of studies that take a more nuanced approach to the circumstances when governance matters leave these questions unresolved. 
on firm performance is second order except when circumstances make it important. This is missed by the existing studies finding a positive relationship between a good governance rating by an index and value creation; because they do not distinguish between these different times and circumstances, they only observe an average, and most firms are not average.

In this Article, we begin the process of developing a more context-sensitive story. ${ }^{18}$ Our thesis is that under certain circumstances the governance attributes scored by the indices can function as credible, observable information about a value-relevant firm characteristic that is imperfectly observable on its own: that firm management is of higher quality than previously believed. ${ }^{19}$ When this signal is present, a firm's share price is higher, resulting in a higher Tobin's Q. The higher share price reflects the market recognition that higher quality managers make value-creating decisions more often.

We test this thesis empirically. We find both that the signaling effect exists and that its strength depends on the details of the environment in which the signal is sent. Sometimes this signal can be expected to matter a great deal — that is, it provides considerable new information about an important firm characteristic that in the particular circumstance is less observable than ordinarily is the case and sometimes, in a less noisy context, it matters less, or perhaps not at all,

\footnotetext{
${ }^{18}$ Martijn Cremers and Allen Ferrell in a fashion precede us in this endeavor by identifying a temporal factor affecting the relationship between a good index score and firm value. They demonstrate a difference between the period before and after the Delaware Supreme Court's decision in Moran v. Household International, 500 A.2d 1346 (Del. 1985), in which the Delaware Supreme Court found the adoption of a poison pill as a defense against a hostile takeover attempt to be a valid exercise of board authority. Martijn Cremers \& Allen Ferrell, Thirty Years of Shareholder Rights and Firm Value, 69 J. FIN. 1167 (2014). However, the Cremers and Ferrell study also presents institutional problems. The form of poison pill involved in the Household case was a generally inadequate flip over-type pill. Only some time later was the current more effective flip in pill developed. See RonALD J. GILSON \& BERNARD BLACK, THE LAW AND FinANCE OF CORPORATE ACQUisitions 740-51 (2d. ed. 1995); Air Products and Chemicals, Inc. v. Airgas, Inc., 16 A.3d. 48 (Del. Ch. 2011).

${ }^{19}$ See John G. Riley, Silver Signals: Twenty-Five Years of Screening and Signals, 39 J. ECON. LiT. 432, 433-36, 46773 (providing background on signaling theory and its applications in finance).
} 
because it provides little or no new information. Our results support not just the familiar (though not well tested) claim that one size of governance does not fit all companies, ${ }^{20}$ but also suggest that what size is right for a particular company can differ over time. We recognize that testing signaling hypotheses is difficult; by definition, they are useful only in circumstances wheninformation asymmetry is high and so the signal may be nuanced. In what follows, we are explicit about a central feature of a signaling hypothesis: that the signal must be credible - that is, it must be costlier to firms that lack the unobservable characteristic whose presence is hypothesized to be signaled. By doing so, we hope to encourage more nuanced, context specific evaluations of the link between governance quality and firm performance.

\section{Theories Linking Good Governance Structures to Measures of Value Creation}

In this Part, we explore the possible links between firms with highly rated corporate governance structures and firms that create more value. The starting point is a more detailed explanation of how each index is constructed. Next we briefly describe Tobin's Q -- the typical measure of a firm's success at creating value. We then suggest three possible (and clearly not mutually exclusive) links that may cause a firm that has a highly rated governance structure also to have a high Tobin's $\mathrm{Q}$. One is that having a structure with a higher rating leads over time to a firm having higher quality managers than would be the case if it had a lower rating. A second is that managers, regardless of quality, are better motivated and informed when operating under a

\footnotetext{
${ }^{20}$ See, e.g., Martin Lipton \& Paul K. Rowe, The Inconvenient Truth About Corporate Governance: Some Thoughts on Vice-Chancellor Strine's Essay, 33 J. CORP. L. 64, 68 (2007) (arguing against imposing a one-size-fits all governance methodology upon corporate managers).
} 
more highly rated governance structure. The third is that having a more highly rated governance structure is under some circumstances a credible signal of having higher quality managers. The result of the signal is an increase in stock price that results in an increase in Tobin's Q. It is this third thesis that we then test empirically.

\section{A. Governance Index Construction}

A corporate governance index is constructed by measuring those governance elements that the index author believes affect the quality of corporate decision making. ${ }^{21}$ For example, the author might include in the index a score for whether a company has a staggered board because, when combined with a poison pill, a staggered board would could require a hostile bidder to run two annual proxy contests before it could proceed with a hostile takeover. ${ }^{22}$ This reduces the attractiveness of the company as a takeover target if its managers are running it poorly and so the company continues to perform poorly. If the author believes that exposing a company's management to capital market discipline improves the company's index rating, then a company that has a staggered board receives a lower governance rating.

The G index contains 24 such governance provisions. A company is scored zero if the author believes the company's status with regard to the provision contributes to value, and scored one if its status with regard to the provision does not. The E index, in turn, is composed of only six of the G index's provisions, each of which is said to relate to the company's ability to protect itself

\footnotetext{
${ }^{21}$ We focus here on the indices because the event study literature typically address events associated with the adoption or elimination of governance attributes that are components of the indicies. For present purposes, we do not need to address the criticism of indices that they do not explain the relative importance of particular elements or the interaction between the elements. See Klausner, supra note 15; Catan \& Kahan, supra note 11.

${ }^{22}$ Air Prods. \& Chems, Inc. v. Airgas, Inc., 16 A.3d 48, 114-15 (Del. Ch. 2011), illustrates the barriers presented by the combination of a staggered board and a poison pill. See Lucian Bebchuk, John C. Coates IV \& Guhan Subramanian, The Powerful Antitakeover Effect of Staggered Boards, 55 STAN. L. REV. 885 (2002) (explaining the operation of a staggered board of directors and that board structure's interaction with a poison pill).
} 
from a hostile control change and hence to reduce both capital market monitoring of company performance and the capital market's ability to discipline poor performance. ${ }^{23}$ With both the G and $\mathrm{E}$ indices, the author scores each attribute and then sums the results to arrive at a firm's governance rating. The lower the total, the better is the firm's rating. Neither index attempts to measure the relative importance of, or interaction among, individual provisions. Nor does it reflect an assessment of whether a particular attribute may matter more or less in different contexts.

\section{B. Tobin's $Q$}

Investors give managers resources to work with. Cash flow in excess of what is returned to investors in the form of dividends, stock buybacks and debt service provides additional resources. Managers use these resources to make real investments. A company's expected future cash flow depends on the quality of the real investment choices the managers make and how profitably they utilize the real assets that they acquire. The greater the expected future cash flow (discounted to present value) that managers can earn from each dollar that they are given to work with, the more value managers create.

Simplifying slightly, Tobin's Q is the ratio of the firm's stock market capitalization to the book value of its assets. ${ }^{24}$ The higher a firm's stock market valuation, the greater, according to the market, is the firm's expected future cash flow discounted to present value. The calculation of the book value of the firm's assets starts with the historical cost of acquiring these assets. So the ratio

\footnotetext{
${ }^{23}$ The six attributes are limits on shareholder amendments to the bylaws, staggered boards, supermajority requirements for shareholder approval of charter amendments, supermajority majority requirements for shareholder approval of mergers, poison pills and golden parachutes. Bebchuk, Cohen \& Ferrell, supra note 12.

${ }^{24}$ More precisely, to account for resources obtained by debt and retained earnings financing, the formula for Q typically used, and used in the study reported here, is the market value of a firm's equity minus the book value of the equity plus the market value of the firm's debt all divided by the book value of its assets. See Clifford W. Smith \& Ross L. Watts, The Investment Opportunity Set and Corporate Financing, Dividend, and Compensation Policies, 32 J. FIN. ECON. 263 (1992).
} 
of the two measures the capacity of a firm's managers to create value from the resources given to them. $^{25}$

\section{Three Theories Explaining the Observed Relationship Between a Good Index Rating and Value Creation}

Theory suggests three explanations for the observed relationship between firms with good index scores and high Tobin's Qs, the measure of creation of shareholder value. They are not mutually exclusive.

1. Higher quality managers. The first explanation is that over time a highly rated governance structure does a better job at filtering out bad managers through monitoring and discipline than one receiving a poor rating. Firm governance structures tend to be fairly stable and so firms with highly rated structures tend to have better managers than firms with poorly rated structures. Better managers create more value because they make better decisions concerning both new investment projects and how to utilize the firm's existing productive capacity. Thus they create more shareholder value, which will be reflect in a higher Tobin's Q. ${ }^{27}$

\footnotetext{
${ }^{25}$ It should be noted that maximizing Tobin's Q is not equivalent to maximizing value creation, i.e. maximizing the value of the expected cash flow from the firm's real investment projects over the cost of implementing these projects. Ex ante, a value maximizing firm must identify value creating real investment projects and then should implement every real investment project proposal that is expected to add more to the value of the firm more than the cost of assets needed implement it. If, however, a firm with an already high Tobin's $Q$ took as its goal the maximization of Tobin's $\mathrm{Q}$, it would not proceed with a project where the ratio of the value it adds to the firm over the cost of the assets to implement it is lower than the firm's current $Q$ even where that ratio is positive, i.e. where the addition to value exceeds the cost of the needed resources. Tobin's Q is still, however, a reasonable way of looking for a historical period of time to see which firms on average did better at creating value and which did worse. It is widely used in this fashion because it is hard to create a test that identifies both the capacity of management to identify the most and the greatest value creating projects and the willingness to go just to the margin, implement all expected value creating projects and no expected value decreasing projects. Growth in share price is not a reliable measure, for example, because the initial price already incorporates the market's then current assessment of management's capacity find value creating projects and willingness to implement them just up to the margin. Where the question under study is the effect of a particular corporate governance provision on firm generation of value, endogeneity issues arise.

${ }^{27}$ From this perspective, the six entrenchment attributes that compose the E index are a last line of defense - really good governance acts internally through devices such as a requirement that a majority of the board be independent,
} 
2. Better motivated and informed managers. A second explanation for the governance structure-performance link is that a particular governance structure may provide greater incentives for a firm's CEO and other managers to make the right decisions. That is, holding the quality of managers constant, a governance structure that receives a high rating causes managers of all levels of ability to make better decisions. For example, a governance structure that makes a firm more open to hostile takeovers provides managers with a greater incentive to perform well because the alternative — performing poorly—is more likely to result in their losing their jobs.

A highly rated governance structure also may provide information and voice to others, for example independent directors or activist shareholders, who can improve the quality of firm decision-making through, respectively, their monitoring of managements' decision-making and their provision of information to the directors that otherwise might not be available to the company. ${ }^{28}$ To illustrate, the recent phenomenon of activist investors providing companies with a detailed alternative strategic plan, often set out in a (very) large PowerPoint deck, may give boards, managers and the market information that they otherwise would not have. Fewer structural barriers to a tender offer or proxy contest translate into a better governance rating under the $\mathrm{G}$ and $\mathrm{E}$ indices, and so provide an incentive for activists to make the effort. Again, a broader range of information inputs into operating decisions, and the imposition of discipline on the decision making process,

weeding out bad managers before outsiders can observe the opportunity for improvement. These six governance attributes that facilitate capital market policing of management at a later date are a backstop if the other devices fail. ${ }^{28}$ See Ronald J. Gilson \& Jeffrey Gordon, The Agency Costs of Agency Capitalism: Activist Investors and the Revaluation of Governance Rights, 113 CoLUM. L. REV. 883 (2013); Ronald J. Gilson \& Jeffrey Gordon, Agency Capitalism: Further Implications of Equity Intermediation, in RESEARCH HANDBOOK ON SHAREHOLDER POWER (J. Hill \& R. Thomas eds., 2015). 
should result in better decisions that lead to greater shareholder value by more and less talented managers alike.

3. Signaling management quality. Each of the first two explanations - more effectively filtering out bad managers and better motivating, monitoring and informing managers of all ability levels - directly affects the quality of firm decision-making; it is this direct increase in decision quality that results in the hypothesized higher level of Tobin's Q. The third possible explanation for the observed relationship between good corporate governance index scores and high Tobin's Qs is the signaling story that is at the center of our analysis. This story involves a very different mechanism than the first two. Instead of a well-rated governance structure leading to higher quality managers as in the first theory, or improving the performance of managers of all ability levels as in the second theory, in the third the direction of causation is reversed: high quality managers choose a high-rated governance structure for the firm.

The signaling hypothesis rests on the fact that managers play a major role in shaping the governance structures to which they are subject because changes in these structures usually come at their initiative. Their choice of a governance structure provides the market with credible information about a highly value-relevant, but not fully observable, firm characteristic: management quality. To see the value of this signal, consider to what else the market might look to assess the quality of a firm's management. One factor is their education and experience. However, education and experience are noisy predictors of future performance. Another factor is past performance. Beyond the actual quality of a firm's managers, however, a cacophony of other elements combine to affect firm performance in any given year. These include external factors such as the overall demand for the output of the industry to which the firm belongs, the success of 
the firm's competitors, and, importantly, plain luck. So, while on average good past performance indicates high quality management, it does not necessarily mean this in any particular case.

Of course, managers themselves have information about their own competence that is not publicly observable. Those managers that have private information suggesting they are of high quality may have a difficult time credibly conveying this information to the market because talk is cheap. Managers (like the rest of us) do not often) disclaim responsibility for good performance or accept it for bad performance.

The signaling hypothesis runs as follows. The market has difficulty distinguishing good managers from poor ones, especially in the short run when, as noted, good luck and good judgment can combine in different proportions that are difficult to observe. The market knows, however, that managers play a major role in shaping the governance structure to which they are subject. When bad managers are subject to a higher rated governance structure, which with the $\mathrm{G}$ and $\mathrm{E}$ indices is increasing in the extent to which the company's governance exposes the company to capital market discipline, they face a greater increase in the risk of losing their jobs than do good managers when subject to the same governance structure. In this circumstance, a management choice of a highly rated governance structure is a signal that the managers believe they are of good quality. However, the signal must be credible. The essence of signaling theory is that the signal imposes differential costs on those who have the unobservable characteristic sought to be signaled and those who do not. The low quality sender must face a higher expected future cost for sending the signal than will the high quality sender will, thereby causing the low quality sender not to send a false signal by choosing a higher rated structure despite their lower quality. A higher rated governance structure is just such a signal if it increases a bad manager's risk of job loss more than 
it increases a good manager's job loss risk. When the market sees a firm whose managers choose a higher rated governance structure, it infers that the firm has better managers. Bad managers would be less likely to expose themselves to an increased job loss risk in order to falsely signal their quality. The stock price of the firm involved is higher as a result of this favorable information, which in turn results in a higher Tobin's Q.

Firm managers who are doing an especially poor job are also likely to know more about how poorly they are doing than the market does. Fearing that potential acquirers or activist hedge funds will soon figure out what a poor job they are doing, managers make changes in their governance structures that provide more protection against a potential takeover and so lower their index scores. In this situation, the change in governance structure sends a negative signal concerning management quality to the market, a signal that will be more powerful when information asymmetry between managers and the market is particularly great.

The linchpin of a signaling hypothesis is that the cost of the signal is higher to one sending a false signal, in our case, that a good governance index score must actually increase the firm's exposure to capital market discipline. As discussed earlier, recent criticisms of index studies argue that there is no plausible causal story linking the governance items scored in the G or E indices with firm value, although they do not take issue with the empirical link between these index scores and firm value. ${ }^{31}$ While we agree with much of this argument, we suggest that there is a plausible story that on average firms that score better (i.e., lower) on the $\mathrm{G}$ or $\mathrm{E}$ indexes will create more value. ${ }^{32}$ The critics might rejoin that this story may not turn out not to be correct, in which case we

\footnotetext{
${ }^{31}$ See note 17 supra and accompanying text.

${ }^{32} \mathrm{Id}$.
} 
would be left unable to identify why making governance changes results in a higher Tobin's Q. Thus, they might say, we would be unable to show why it would be more costly for low quality managers to adopt a score improving governance change than for high quality managers, in which case such a governance change would not be a credible signal of managerial quality. Resolving this issue is difficult because the effectiveness of particular defensive techniques is contextual: the circumstances of a particular company may cause a technique that may not be generally effective to be protective in particular circumstances. As a result, the presence of effectiveness and so the credibility of the signal may be one off, and so more difficult to observe.

In a situation where context matters, it is sufficient to note that that score improving governance changes has been shown empirically to increase Tobin's Q. If it were not costly to the managers of at least some firms to improve their governance score, every firm would do it, and all companies would change their governance during the sample period. We observe that this is not the case, and hence the inference that whatever is the arguably still unidentified link between governance structures with good scores and performance, difficult to identify because in a situation where context matters, a score improving governance change would be costly to the firm managers who do not choose to change.

Recent empirical evidence is consistent with the hypothesis that score improving governance changes are more costly for low quality managers. Vicente Cuñat, Mireia Giné and Maria Guadalupe report that approval of a precatory shareholder proposal to remove an antitakeover proposal listed in the $\mathrm{G}$ index results in an increase of 12 to 14 percent in the cumulative probability that the firm will be the target of a successful takeover within 5 years after the vote on a sample composed of all shareholder-sponsored proposals to remove an antitakeover provision voted on in 
annual meetings of S\&P 1500 firms between 1994 and 2013 (2809 proposals in 929 different firms). ${ }^{33}$ This suggests that a governance change that leads to an improvement in a governance index rating does in fact leave firms more vulnerable to takeover, a result which would be differentially costly to low quality managers.

\section{Testing the Signaling Theory}

The three theories explaining the observed relationship between firms with highly rated governance structures and greater value creation are not by their terms mutually exclusive. The existing studies that show this relationship do not allow us to distinguish whether one, two or all three of the relationships in fact are at work. Here we begin to sort out the question of which relationships are operative by showing that the third explanation - the hypothesis that managers choose high index ratings corporate governance structures as signaling devices - is, at least under the right circumstances, consistent with quite powerful empirical results and therefore can play an important role.

Our starting point is a time period when the market was unusually uncertain about the quality of the managements of individual U.S. firms. According to our hypotheses, if firms that improved their governance index ratings during such a period experienced larger changes in Tobin's Q than did firms that changed their structures in other years, signaling is likely at work. The idea is

\footnotetext{
${ }^{33}$ Supra Note 17. The finance literature also suggests that a similar kind of signaling can be involved when managers make capital structure decisions. The logic is that an increase in debt increases the risk of bankruptcy. Bankruptcy, in turn, is costly to managers; the value of their human capital, which is not diversified, is reduced if the company fails. Bankruptcy is less likely for good managers than bad managers, so when managers increase the amount of debt in their company's capital structure, they credibly signal their own quality: the signal would be too costly to bad managers for it to be in their interest to fake. See Bengt Holmstrom \& Jean Tirole, The Theory of the Firm, in 1 HANDBOOK OF INDUSTRIAL ORGANIZATION 61, 78-86 (Richard L. Schmalansee \& Robert Willig eds.1987).
} 
straightforward: if an action has a bigger effect on stock prices and hence Tobin's Q in periods when the market is less informed, the action must be something that provides information to the market. As documented below, the two-year period 2001-2002 was clearly such a period. During this period, the United States was rocked by a series of corporate accounting scandals affecting large respected firms. These scandals called into question the reliability of the earnings reports of all the nation's public companies. The market reasonably wondered whether there were more shoes still to drop.

We report two key findings with respect to this period. First, the impact on Tobin's Q of firms that changed their structures in 2001-2002 was substantially greater than for firms that changed their structures in the thirteen years surrounding this period. Second, the overall relation between firm index ratings and Tobin's Q, measured across all firms (which includes the vast majority that did not change their governance structures), is not significantly different during 2001-2002 than in the other thirteen years. This second finding suggests that the market did not think during this period that governance structures with higher ratings were any more effective creating value, or at least not sufficiently more effective to generate a statistically significant result. In other words, the second finding shows there is no significant evidence that either of the first two theories explaining the positive relation between good governance ratings and Tobin's Q — filtering out bad managers and better incentivizing and informing managers - were working any differently in the 2001-2002 period than in other years.

This leaves the third explanation -- signaling -- to explain why governance changes in the 2001-2002 period had a greater impact on Tobin's Q than in the surrounding 13 years. If signaling does in part explain the positive relationship between good governance ratings and firm value, one 
would expect to see a bigger effect when there is more doubt about the subject of the signalmanagerial quality. This is exactly what we see. ${ }^{34}$

\section{A. The Millennial Accounting Fraud Scandals}

The 2001-2002 period was special in U.S. corporate history because of the revelation of an unprecedented cascade of accounting frauds. In the years immediately preceding these revelations, there appears to have been a buildup, unknown to the market, of these kinds of frauds. The possible reasons for this buildup include a proliferation of short-time-horizon share price-based executive compensation packages, which create greater incentives for manipulating the numbers as well as for genuinely better performance, and an apparent decline in the effectiveness of the various gatekeepers against fraud such as accountants, rating agencies, investment banks and lawyers. ${ }^{35}$ Warren Buffet is famously quoted as saying "[Y]ou only find out who is swimming naked when the tide goes out," 36 and the recession that hit the country shortly after the beginning of the new

\footnotetext{
${ }^{34}$ This story can be subject to refinement, but the basic message remains unchanged. During 2001-2002, the economy experienced three other significant events beyond the wave of accounting scandals: the Dot Com bust as reflected in the March 2001 NASDAQ market crash; the beginning of a recession in March 2001; and the September 11, 2001 World Trade Center terrorist attacks. These kinds of event driven pressure on a firm's business environment raise questions about existing strategies and generally disrupt business as usual. By increasing the choices confronting a company, such event should make the quality of management become more important. See Edward G. Fox, Merritt B. Fox \& Ronald J. Gilson, Economic Crisis and the Integration of Law and Finance: The Impact of Volatility Spikes, 116 COLUM. L. REV. 325, 344 (2016). If, as we would expect, management quality became more important to the market in 2001-2002, we would expect an accentuation of the effects of good ratings on Tobin's Q that are at the heart of the first two theories. Our second finding - an absence of significant evidence that the overall relation between firm index ratings and Tobin's Q, measured across all firms is not significantly different during 2001-2002 than in the other thirteen years - means that we do not have empirical support for that expectation. This may well be that our tests do not have the power to detect the accentuation that we would expect, rather than that it did not occur. The important point is that tests with similar power are behind our first finding of a large increase in the impact on Tobin's Q from firms that changed structure when comparing 2001-2002 to the other thirteen years. So, these other events in the economy and their effects on the workings of the first two theories cannot explain much of our first finding, which still leaves the third theory - signaling - as the likely explanation.

${ }^{35} \mathrm{See}$ John C. COFFEe, JR., GateKeEPERS: The Professions AND Corporate GOVERnANCE (2006); Merritt B. Fox, Gatekeeper Failures: Why Important, What to Do, 106 Mich. L. REV. 1089 (2010).

36 Letter to the Shareholders of Berkshire Hathaway Inc. 10 (Feb. 28, 2002), http://www.berkshirehathaway.com/letters/2001pdf.pdf [http://perma.cc/QUJ7-X8PG].
} 
millennia seems to have served that function with respect to this buildup of frauds. Some of the most prominent and, at the time, respected corporations in the country, including Enron, WorldCom, Health South and Adelphia, were severely damaged or destroyed by senior management fraudulent criminal behavior relating to material misstatements or omissions about firm performance in the company's financial statements. Each of these scandals warrants a brief history to give the reader a sense of why they spread such doubt across the rest of corporate America. $^{37}$

1. Enron. Enron was the poster child for the phenomenon. In August 2000, Enron's stock Enron's stock peaked at nearly ninety dollars per share and the company had been listed as America's most innovative firm for five consecutive years. ${ }^{38}$ The company had been repeatedly touted as having impressive management and among the best boards of directors. ${ }^{39}$ In a year's time, following the revelation of massive fraud, Enron would enter Chapter 11 bankruptcy as the largest bankruptcy filing in American history. ${ }^{40}$

Perhaps most famously, Enron sponsored hundreds of special purpose entities ("SPEs") that it claimed in essence insured it against the downside risks associated with many of the assets it acquired. In the typical transaction, Enron would inappropriately capitalize the SPE with its own

\footnotetext{
${ }^{37}$ For an extensive list of companies faced with accounting scandals from 2001-2002, including Xerox, Merck, Tyco, and Bristol-Myers Squibb, see Penelope Patsuris, The Corporate Scandal Sheet, Forbes, http://www.forbes.com/2002/07/25/accountingtracker.html (last updated Aug. 26, 2002, 5:30 PM).

${ }^{38}$ William W. Bratton, Enron and the Dark Side of Shareholder Value, 76 TulanE L. REV. 1275, 1276 (2002).

${ }^{39}$ See Jeffrey A. Sonnenfeld, What Makes Great Boards Great, Harvard Business Review (Sept. 2002), available at https://hbr.org/2002/09/what-makes-great-boards-great ("[N]o corporation could have had more appropriate financial competencies and experience on its board [than Enron]."). Less than a year before the company declared bankruptcy, Fortune Magazine ranked Enron second in 'quality of management' among all U.S. corporations. See Coffee, supra note 31 , at 18 .

${ }^{40} \mathrm{Id}$. at 1342 .
} 
stock. ${ }^{41}$ The SPE would provide Enron with a put, whereby Enron had the right to sell the asset to the SPE for a specified price. ${ }^{42}$ This arrangement had an inherent problem: if the value of the asset and the value of Enron stock both fell, the SPE would have insufficient assets to perform, exactly at the moment when the protection of the put against downside risk would be most important. ${ }^{43}$ Moreover, even if the SPE did manage to perform, Enron had created an arrangement that in effect violated one of accounting's most fundamental principles: the proceeds from the issuance of new equity should not be counted as earnings. Investors in Enron were unaware of the endogenous nature of these SPE arrangements. ${ }^{44}$

Enron "stretched the limits of accounting" 45 in other ways as well. Enron valued certain of its varied assets on a "mark-to-market" basis in a way that allowed the company to recognize as current income what was really just forecasted future income on a long-term contract. ${ }^{46}$ As an example, in July 2000, Enron entered into a twenty-year partnership with Blockbuster Inc. to develop a company that would provide films to customers through Enron's fiber-optic cables. ${ }^{47}$ Enron assigned a $\$ 124.8$ million value to the partnership based on its projection of future revenues, and from this counted profits of $\$ 53$ million and $\$ 58$ million as current earnings, respectively, in the last quarter of 2000 and first quarter of 2001, while, for the same quarters, Blockbuster

\footnotetext{
${ }^{41}$ Steven L. Schwarcz, Enron and the Use and Abuse of Special Purpose Entities in Corporate Structures, 70 U. CIN. L. REV. 1309, 1310 (2002).

${ }^{42} I d$.

${ }^{43}$ Id. at $1315-16$.

${ }^{44}$ Paul M. Healy \& Krishna G. Palepu, The Fall of Enron, J. ECON. PERsPS. 3, 11.

${ }^{45} \mathrm{Id}$. at 9.

${ }^{46} \mathrm{Id}$. at 10.

${ }^{47}$ Benston \& Hartgraves, supra note 12, at 116.
} 
attributed no profits to the deal. ${ }^{48}$ The partnership was ultimately dissolved in October 2001, and Enron had to reverse the earlier reported earnings. ${ }^{49}$

Beginning in 2001, Enron's stock began to decline for reasons unrelated to the accounting fraud, which had yet to be detected. ${ }^{50}$ The declining share price, among other things, left the SPEs with negative equity and in October 2001 Enron was forced to announce that it had violated a variety of accounting standards. ${ }^{51}$ As a result of these accounting revisions, the company restated its financial statements for years 1997 to 2000, reduced total earnings by $\$ 613$ million, increased liabilities by $\$ 628$ million, and removed $\$ 1.2$ billion of shareholder equity. ${ }^{52}$ Only two months later, Enron filed for bankruptcy with assets of $\$ 63.4$ billion, marking the largest restructuring in U.S. history. ${ }^{53}$

Enron's failure, and the inability of its information gatekeepers — namely the auditors, rating agencies, and investment banks — to detect the financial malfeasance ${ }^{54}$ would effectively "call[] the American market's integrity into question."55 Similarly, commentary at the time by prominent academics saw Enron as illustrative of more general problems. Healy and Palepu noted that "the problems of governance and incentives that emerged at Enron can also surface at many other firms and may potentially affect the entire capital market." J6 Jeffrey Gordon questioned whether "[t]he

\footnotetext{
${ }^{48} I d$.

${ }^{49} I d$.

${ }^{50}$ Bratton, supra note34, at 1322.

${ }^{51}$ Healy \& Palepu, supra note40, at 11.

${ }^{52} I d$.

${ }^{53}$ Benston \& Hartgraves, supra note 12, at 106.

${ }^{54}$ See Coffee, supra note 31.

${ }^{55}$ Bill Mann, Outraged Over Enron, THE MOTLEY FoOL (Jan. 17, 2002), http://www.fool.com/news/foth/foth020117.htm.

${ }^{56}$ Healy \& Palepu, supra note40, at 4.
} 
real concern is that the gross overreaching at Enron is symptomatic of troubling if not egregious behavior elsewhere." 57

2. WorldCom. WorldCom's accounting fraud was less sophisticated than Enron's but had similar consequences. WorldCom's CEO and CFO (Bernard Ebbers and Scott Sullivan respectively) were widely regarded as one of the best executive pairings in American business. ${ }^{58}$ Between 1985 and 2001 WorldCom acquired more than seventy companies for over $\$ 100$ billion, including its 1998 merger with MCI Communications in a transaction valued at \$37 billion, at the time the largest merger in history. ${ }^{59}$ By 2001 it was the second largest U.S. long-distance telephone company and the largest provider of internet services. ${ }^{60}$

WorldCom maintained its capacity to provide long distance phone service in part by entering into long-term leases to use the lines of other telecom firms. ${ }^{61}$ These leases would often require WorldCom to make fixed monthly payments regardless of utilization. By 2000, these line costs were WorldCom's largest expense item and represented nearly half of its operating costs. ${ }^{62}$ Analysts and commentators of the telecommunications industry focused heavily on the line cost expenditure-to-revenue $(\mathrm{E} / \mathrm{R})$ as an important performance indicator. ${ }^{63}$ Over this period

\footnotetext{
${ }^{57}$ Jeffrey N. Gordon, What Enron Means for the Management and Control of the Modern Business Corporation: Some Initial Reflections, 69 U.Chi. L.Rev. 1249 (2002).

${ }^{58}$ Arthur E. Wilmarth, Jr., Conflicts of Interest and Corporate Governance Failures at Universal Banks During the Stock Market Boom of the 1990s: The Cases of Enron and WorldCom, in CORPORATE GOVERNANCE IN BANKING: A GLOBAL PERSPECTIVE 113 (Gup ed. 2007), at 113.

${ }^{59}$ J. Randel Kuhn, Jr. \& Steve G. Sutton, Learning from WorldCom: Implications for Fraud Detection Through Continuous Assurance, 3 J. EMERGING TECH. IN ACCT. 61, 63 (2006).

${ }^{60} I d$.

${ }^{61}$ Wilmarth, supra note54, at 114.

${ }^{62} \mathrm{Id}$.

${ }^{63} I d$. at 63 .
} 
WorldCom consistently recorded an E/R ratio of $42 \%$, significantly lower than its competitors, a ratio that it struggled to maintain as market conditions tightened, ultimately through use of fraud. ${ }^{64}$

WorldCom's accounting fraud took two principal forms - an understatement of its line costs and an exaggeration of its revenues - with the objective of anchoring the E/R ratio at $42 \%$ and reporting double-digit revenue growth. ${ }^{65}$ WorldCom manipulated its line costs by improperly releasing accruals set aside on its financial statements to pay anticipated bills in the future. Accounting accruals were intended to reflect an estimate of the costs associated with using the lines and facilities of outside vendors for which WorldCom had not yet paid. ${ }^{66}$ Releasing an accrual signals, in this case without a sound basis, that less is needed to pay the bills than had been previously anticipated, thereby reducing reported expenses and increasing pre-tax income. ${ }^{67}$ By the end of 2000 WorldCom had exhausted the available accruals needed to continue this manipulation of line costs. ${ }^{68}$

Once these accruals had been depleted, WorldCom shifted to other forms of accounting fraud. It capitalized, rather than expensed, $\$ 3.8$ billion of the company's cash outlays for line costs during 2001 and the first quarter of $2002 .{ }^{69}$ Under GAAP, operating expenses must be deducted from gross revenues to calculate earnings, whereas cash outlays for capital are not charged against revenue under the theory that capital outlays acquire longer lasting assets that will be available to generate revenues in future periods and be matched against depreciation or amortization of the

\footnotetext{
${ }^{64}$ Kuhn \& Sutton, supra note55, at 63.

${ }^{65}$ Dennis R. Beresford, Nicholas deB. Katzenbach \& C.B. Rogers, Jr., Report of Investigation by the Special Investigative Committee of the Board of Directors of WorldCom, Inc. 9 (March 31, 2003), available at https://www.sec.gov/Archives/edgar/data/723527/000093176303001862/dex991.htm.

${ }^{66} I d$. at 10.

${ }^{67} I d$.

${ }^{68} I d$. at 11 .

${ }^{69}$ Wilmarth, supra note 58, at 115.
} 
capital outlay. ${ }^{70}$ Since these line cost outlays were in fact expenses needed to provide the services that generated current revenues and acquired nothing useful for generating future revenues, WorldCom was again able to inflate net income. ${ }^{71}$ Had WorldCom not inappropriately capitalized its line costs, it would have reported a pre-tax loss in three of the five years in which the scheme went on, and would have had E/R ratios consistently exceeding $50 \% .^{72}$

WorldCom met a fate similar to Enron. The company filed bankruptcy in July $2002,{ }^{73}$ ultimately issuing a final restatement that, in its correction of the accounting frauds, reduced its previous reported pre-tax earnings by $\$ 10.6$ billion. $^{74}$ WorldCom's CEO was sentenced to 25 years in prison. ${ }^{75}$ Its $\mathrm{CFO}$ received a prison sentence as well and it director of general accounting and several of his employees pled guilty to conspiracy and securities fraud charges. ${ }^{76}$ As with Enron, the press response to the WorldCom scandal saw it as indicative of systemic failure in the quality of the financial disclosure provided by U.S. public corporations. In the words of the Economist at the time, "WorldCom may also mark the point when investors, particularly foreigners, finally lose all confidence in American accounting.",77

\footnotetext{
70 The outlays for capital assets are ultimately counted against revenue, but this is done in future periods in the form of deductions for depreciation that are spread over the useful life of the asset. Kuhn \& Sutton, supra note 59, at 6364

${ }^{71}$ Lyke \& Jickling, supra note _, at 2.

${ }^{72}$ Beresford et al., supra note $\overline{65}$, at 11-12.

${ }^{73}$ Wilmarth, supra note 54, at 115.

${ }^{74} \mathrm{Id}$.

75 Jennifer Bayot \& Roben Farzad, Ex-WorldCom Officer Sentenced to Five Years in Accounting Fraud, N.Y. TIMES (Aug. 12, 2005), http://www.nytimes.com/2005/08/12/business/exWorldCom-officer-sentenced-to-5-years-inaccounting-fraud.html.

${ }^{76}$ Kathleen Brickley, From Enron to WorldCom and Beyond: Life and Crime After Sarbannes-Oxley, 81 Wash. U.L.Q. 357, 372 (2003).

77 WorldCom and Financial Markets: Another Scandal, Another Scare, THE ECONOMIST (June 27, 2002), http://www.economist.com/node/1205302.
} 
3. Health South. Health South involved even cruder tactics to exaggerate earnings than did WorldCom. In order to maintain the appearance of growth, near the end of each reporting quarter Health South's CEO and a group of executives picked a desired earnings-per-share figure in light of existing analyst expectations, which was then forwarded to the assistant controller. ${ }^{78}$ The controller would in turn work with a handful of finance and accounting executives, known internally as "the family," to plug the gap between desired and actual earnings. ${ }^{79}$ These executives did so by falsifying accounting entries for cash, inventory, and assets. ${ }^{80}$ After the fraud was revealed, bankruptcy ensued, and all five HealthSouth CFO's during the period of the fraud pled guilty to criminal indictments. ${ }^{81}$ As with the Enron and WorldCom scandals, Health South was said to put at issue not only the fabricated value of HealthSouth's stock, but represented as well "a fundamental attack on the core of the public market: accurate and transparent pricing information." $" 82$

4. Adelphia. The scandal at Adelphia included the added twist that part of the accounting fraud covered up significant self-dealing between Adelphia and the family that controlled it. Adelphia Communications, a publicly traded but family controlled cable company, had by 2002 become the sixth largest U.S. cable company, with annual revenues of $\$ 2.9$ billion and over five and a half million subscribers across 32 states. ${ }^{83}$ As it turned out, however, Adelphia had been manipulating its financial reports since the company went public in 1986 according to the

\footnotetext{
${ }^{78} \mathrm{Id}$.

${ }^{79} \mathrm{Id}$.

${ }^{80} \mathrm{Id}$.

${ }^{81}$ Carrick Mollenkamp, An Accountant Tried in Vain to Expose HealthSouth Fraud, WALL ST. J., http://www.wsj.com/articles/SB105338447947754000 (last updated May 20, 2003, 12:01 AM).

${ }_{82}^{82}$ Id. at 131.

${ }^{83} \mathrm{Id}$.
} 
testimony of a former vice president of finance, James R. Brown, who pled guilty to securities fraud and bank fraud. ${ }^{84}$ Brown stated that he and other Adelphia Officers regularly fabricated statistics on the number of subscribers, cash flow, cable-system upgrades, and other closely followed metrics. ${ }^{85}$

In another example of fictiously converting cash outlays for operating expenses into outlays that could be capitalized, Adelphia allegedly agreed with two suppliers of digital set-top boxes to pay $\$ 7$ million too much for the boxes. In return, the suppliers agreed to provide Adelphia with an equal amount in "marketing support." The additional outlay for the boxes was capitalized and thus did not count against earnings. The market supported saved $\$ 7$ million in expenses, boosting Adelphia's reported earnings. ${ }^{86}$ The company's audit committee met, for example, only once in $1999^{87}$ and, for the last half of 2000 until April of 2002, consisted of only two members, one outside director and a member of the controlling Rigas family. ${ }^{88}$ Finally, Adelphia's accounting fraud was accompanied by extensive self-dealing by the Rigas family, which, of course, was not disclosed in the company's financial statements.

In April 2002, Adelphia delayed the filing of its annual 10-K report with the SEC, in part due to disagreements with its auditor Deloitte \& Touche. ${ }^{89}$ The SEC simultaneously opened an informal inquiry to investigate the company's accounting methods, ${ }^{90}$ and the company was forced

\footnotetext{
${ }^{84}$ Barlaup et al., Restructuring Trust in Auditing,: Ethical Discernment and the Adelphi Scandal, 24 Managermail Auditing 183, 192 (2009).

${ }^{85} \mathrm{Id}$. at 195.

${ }^{86} I d$.

${ }^{87} I d$. at 194.

${ }^{88} \mathrm{Id}$.

${ }^{89} \mathrm{Id}$.

${ }^{90} I d$.
} 
into bankruptcy by June 2002. ${ }^{91}$ John Rigas was convicted by a jury on charges of fraud and conspiracy for stealing more than $\$ 100$ million in company funds and hiding more than $\$ 2$ billion in debt incurred by the family through entities involving Adelphia. ${ }^{92}$ The Wall Street Journal, writing at the time, noted that the charges brought by the federal government in the immediate aftermath of the fraud represented the latest effort "to crack down on corporate malfeasance as public confidence and the financial markets have been battered by seemingly relentless disclosures of financial shenanigans." 93

5. Overview: The Situation of Investors. Consider the situation of market participants as this cascade of scandals rained down. They would have a heightened fear that some other firms, as yet untarred by scandal, would also ultimately be revealed as also having used fraudulent accounting practices. This fear would call into question the accuracy of public information concerning the performance of the still untarred companies, resulting in a serious problem. Market participants would have recognized there was a distribution of managerial quality among firms, a very important firm characteristic to investors. But fear about the reliability of the information about each firm would have raised questions about whether their previous assessments of management quality were correct, particularly because the scandals took place at some of the country's most respected companies. Press accounts from this period describe that investors came to harbor suspicion that financial statements more generally were subject to fraud risk but were uncertain as to who were the bad actors. A statement by Brett Truman, an accounting professor

\footnotetext{
${ }^{91} I d$. at 192.

92 Peter Grant \& Christine Nuzum, Adelphia Found and One Son Are Found Guilty, WALL ST. J., http://www.wsj.com/articles/SB108862065449551734 (last updated July 9, 2004, 12:01 AM).

93 Jerry Markon \& Robert Frank, Adelphia Officials are Arrested, Charged with 'Massive' Fraud, WALL ST. J., http://www.wsj.com/articles/SB1027516262583067680 (last updated July 25, 2002, 12:01 AM).
} 
from the University of California-Berkeley's Haas School of Business, captures the concern: "This is why the market keeps going down every day - investors don't know who to trust. As these things come out, it just continues to build up." 94

In this circumstance, high quality firm managers would have had an unusually strong incentive to design a signal that that credibly conveyed to the market the accuracy of their financial disclosures and hence the managers' quality — that performance was based on skill, not fraud. ${ }^{95}$ In a period when the market was surprised by a pattern of fraud in respected exchange-listed companies, equity holders could be uncertain of their ability to distinguish between companies with honest managements and those without. Accordingly, the market would discount every company for the chance that it was a "hidden" bad company—in effect, a pooling equilibrium. This discounting would create a strong incentive for honest, capable managers to find ways to signal their companies' high quality. Managers who succeeded in freeing themselves from suspicion by the use of such a signal would separate themselves from the lemons-like market pooling and so see their companies' share prices rise. This would both reduce the cost of equity finance and provide the variety of other benefits that managers enjoy from higher share prices. ${ }^{96}$

\section{B. Overview of the Empirical Study and Its Results}

The findings that we report below strongly suggest that during the 2001-2002 period, firm managers did successfully use changes in their companies' governance structures as a signal of

\footnotetext{
${ }^{94}$ See David Hancock, World-Class Scandal at WorldCom, CBS NEws, http://www.cbsnews.com/news/world-classscandal-at-worldcom/ (last updated June 26, 2002, 9:23 AM).

${ }^{95}$ See Stewart C. Myers \& Nicholas S. Majluf, Corporate Financing and Investment Decisions When Firms have Information that Investors Do Not, 13 J.Fin. ECON. (1984) and Lakshmi Shayam-Sunder \& Stewart C. Myers, Testing Static Tradeoff Against Pecking Order Models of Capital Structure, 51 J. FIN. ECON. 219 (1999).

${ }^{96}$ The use of capital structure as a signaling technique, by adding new information, sidesteps the Miller-Modigliani equivalence propositions. See Bolton \& Tirole [insert cite]
} 
their quality. Our study employs the two well-known governance indices discussed above, the G index and the $\mathrm{E}$ index. Treating $\mathrm{G}$ index and $\mathrm{E}$ index ratings, respectively, as the independent variable, we use a linear regression analysis to see what on average happens to a firm's Tobin's Q, the dependent variable, when there is a difference in the rating. For a large sample of firms for the years 1992-2006, we run two kinds of econometric tests: an ordinary least squares (“OLS”) test and a fixed effects test. We then subdivide this large sample into two subsamples, one covering the accounting scandal years 2001-2002 and the other covering the surrounding thirteen years and run the two kinds of tests on each of the subsamples. We compare the results for each of the tests in the two years of the governance scandal - 2001 and 2002 — with the results for each of the tests for all the other years in our longer period.

1. The nature of OLS and fixed effects tests. It is useful at the outset to briefly describe the nature of these two econometric tests because the signaling analysis is driven by the differences between them. In the OLS test, the sample being tested consists of the pairing of the index rating and the Tobin's Q for each firm in the sample for each year that it is in the sample. The assumption is that across this sample, the other not-tested factors that affect the firm's Tobin's Q beyond the firm's governance rating are randomly distributed. ${ }^{97}$ This means that, for any given firm in any given year, these other factors are as likely to boost $\mathrm{Q}$ above, as to diminish $\mathrm{Q}$ below, what the impact of the rating on Q would have been if the rating were the sole factor at work.

In a fixed effects test, the sample being tested consists of the pairing of the index rating and the Tobin's Q for each firm in the sample for each year that it is in the sample when the firm

\footnotetext{
${ }^{97}$ These are factors that are not included in the regression as additional independent variables, perhaps because they are not easily observable.
} 
changed its governance structure in a way that altered its rating. This approach is typically used to guard against an omitted variable problem that can arise with an OLS test. That is, the fixed effects regression seeks to control for the possibility that the other non-tested factors that affect Q beyond the firm's governance rating are not randomly distributed and that one or more of these untested factors correlate with the firm's governance rating.

If there is such a positive correlation, an OLS result that shows a positive relation between a good governance rating and Tobin's Q could be partially, or possibly entirely, due instead to the untested factor or factors. However, as long as the other untested factor or factors are time invariant in their influence on Tobin's Q - i.e., have a fixed effect - a regression that, out of all the observations of all the firms in all the sample years, is only run on the firms that in any given year changed its governance structure in a rating altering way avoids this omitted variable problem. This is because the other factor or factors will have the same impact on Tobin's Q before and after the governance change and so the test isolates the effect on Tobin's Q of just the governance change.

2. Summary of our findings. Consistent with the earlier studies, our cross-sectional OLS test for the entire fifteen-year period finds a highly significant positive relationship, both statistically and economically, between firms with good governance ratings and Tobin's Q. Also consistent with previous studies, our fixed effects test for the entire fifteen-year period similarly shows a highly significant positive relationship, both statistically and economically, between a score-improving governance change and Tobin's Q.

Comparing the 2001-2002 period with the other years in the sample, however, yields a very different result: the fixed effects test results diverge sharply from the OLS test results. The fixed 
effects tests reveal that an improved governance score in the scandal years is associated with a much larger increase in Tobin's Q than a comparably sized improvement occurring in other years. This difference between 2001-2002 and the other years is highly significant both statistically and economically. In contrast, the OLS tests show no significant difference between the 2001-2002 period and the other years in terms of the relationship between a firm's governance score and its Tobin's Q.

3. Implications of our findings. This difference between the fixed effects comparison and the OLS comparison strongly suggests that signaling was at work. If a highly rated governance structure, whether through filtering out bad managers or through a more effective incentive effect, leads to better corporate decision-making, then over time it will lead to higher cash flows available for shareholders. And if, in a given year, a firm changes its structure in a way that leads to a higher governance score, the anticipation of the resultant increased cash flows in the future will, in an efficient market, lead to an immediate increase in share price and hence an improvement in its Tobin's Q. This immediate increase would occur even if the market knew everything there was to know about the current quality of the firm's management. Our results, both OLS and fixed effect, for the non-scandal years of 1992-2000 and 2003-2006 are consistent with this story. The OLS result suggests that good structure, through filtering or incentives, leads to better management performance and so more value creation for shareholders; the fixed effect result in turn suggests that the market anticipates this greater value creation when a firm undertakes a governance-ratingincreasing change in its structure.

The OLS finding includes all firms for all years in the sample under study, both the large majority that did not change its structure in a given year and the small minority that did. In terms 
of the filtering effect and the incentive and information effect, the market will not care whether a firm has a high rating because of a recent change in structure or has had the same highly rated structure for some time. Better structures, under these first two theories, lead to better, more incentivized and better informed managers that will make decisions that generate more cash flow in the future whether there has just been an improvement in structure or it has been in place for a longer time. The fact that the OLS finding for 2001-2002 is not significantly different from the OLS finding for these other years suggests that the market's perception of the filtering and incentive effects of a good corporate governance structure for all firms did not change during these two years. Put differently, the filtering and incentive effects of better governance would not differ because of the corporate scandals.

Given this equivalence, suppose, contrary to the signaling hypothesis, the market knew everything there was to know about the quality of each firm's management. There is no reason to think that a firm that made a score-improving change in its structure would, because of the anticipation of better decision making and resultant increased future cash flows, enjoy a greater immediate increase in price in the 2001-2002 than would a firm making such a change in the other years in our sample.

Yet our fixed effects result shows that a firm that made a score improving change in 20012002 experienced a substantially greater immediate increase in stock price and therefore Tobin's Q than associated with changes in the other years. Thus something more must have been going on than what is explained by the filtering or incentive theories. For the firms that made scoreimproving governance structure changes in 2001-2002, the market must initially have had incomplete knowledge about management quality and must have learned something positive about 
management quality from the fact of the governance change. In other words, there is strong evidence that governance changes in 2001-2002 had a significant signaling effect.

The reality, of course, is the market also did not know everything about management in 19962000 and 2003-2006. The extent of uncertainty about the quality of management, however, increased in 2001-2002. Thus our evidence that there was a signaling effect in 2001-2002 -- the greater fixed effect result for 2001-2002 relative to other years - suggests as well the more general conclusion that a management decision to change its firm's governance structure has a signaling effect even in non-governance-scandal years. If so, what we see in 2001-2002 is that the signaling effect is simply much larger: the market, in this period and prior to receiving the signal, was unusually uncertain about the quality of management of the firms involved because of the unexpected incidence of frauds in respected companies.

\section{Data Sources and Variables Used}

As previously described, our study employs the two well-known governance indices discussed above: the Gompers, Ishii and Metrick's $\mathrm{G}$ index ${ }^{98}$ and the Bebchuk, Cohen and Ferrell's E index. ${ }^{99}$ For each of these indices, we run a firm-level fixed effects regression on the relationship between the change in a firm's index score and the change in the firm's Tobin's $Q$ for the years 1992-2006. We also run, for each index, an ordinary least squares (OLS) regression on the crosssectional relationship between a firm's index score and Tobin's $Q$ for the same years. We then compare, for both the fixed effect and OLS tests, the results in the two accounting scandal years2001 and 2002 - with the results for the surrounding years in our sample.

\footnotetext{
${ }^{98}$ Gompers et al, supra note 12 .

${ }^{99}$ Bebchuk et al., supra note 12.
} 
We focus on all publicly traded companies which have a $\mathrm{G}$ index score. For ease of reference, we give our variable names in italics. As noted earlier, the $\mathrm{G}$ index quantifies shareholder rights with regard to a number of matters, including a number of factors suggesting less capacity by incumbent management to resist hostile takeover. ${ }^{100}$ A firm's score can vary from a minimum of zero to a maximum of 24. A lower score and is interpreted as reflecting a better corporate governance structure. The E index consists of six of the G Index items, which are interpreted as allowing management to isolate the company from capital market disciple: staggered boards, limits to shareholder bylaw amendments, poison pills, golden parachutes, supermajority requirements for mergers and limits to charter amendments. ${ }^{101}$

For the above set of firms we obtain financial data from Standard and Poor's Annual Compustat database. Consistent with the previous literature, firm performance is proxied by Tobin's Q. Following that literature, we calculate Tobin's $Q$ as the market value of a firm's equity minus book value of equity plus the market value of a firm's debt divided by the book value of its assets. ${ }^{102}$ We winsorize the values of Tobin's Q at the one-percent level and 99-percent level, so that outliers do not significantly affect our results.

We control for four firm-specific variables that might independently affect firm performance independent of the effect of the governance indices. The first variable is the firm's ratio of debt to total assets $(D e b t)$, which is calculated as the ratio of short-term debt plus long-term debt to total assets. The second is the firm's ratio of research and development expenses to total assets $(R \& D)$.

\footnotetext{
100 See TAN 12-14 supra.

${ }^{101}$ We obtain data for the Gindex and Eindex from Martijn Cremers.

102 See Smith \& Watts, supra note 24; Hyun-Han Shin and Rene M. Stulz, Are Internal Capital Markets Efficient?, 113 Q.J. ECON. 531 (1998); Darius Palia, The Endogeneity of Managerial Compensation in Firm Valuation, 14 REV. FIN. STUD. 735 (2001).
} 
In many cases the firm has missing data for research and development expenses. Rather than discard these observations, we set a dummy variable RDdum to unity for missing data, and equal to zero when not missing. Additionally, $R \& D$ is set to zero in such cases. This implies that missing research and development expenses does not significantly affect the slope or sensitivity of $R \& D$ to Tobin's Q. The final two variables are related to the firm's size. Specifically, we include the natural logarithm of total sales (Lsales), and for any nonmonotonic effect we also include its square (Lsales2).

We present the summary descriptive statistics of these variables in Table I. We have 26,098 observations, consisting of 3,516 unique firms for the years 1992-2006. We find the average Tobin's $\mathrm{Q}$ to be 1.004 , which is higher than the median value of 0.674 . There is substantial variation, which assuming Tobin's $Q$ to have a normal distribution, can vary between -1.249 and 6.17. In the lower tail of the distribution we find negative values, as the market value of equity is less than the difference between the book values of equity and debt. The average Gindex is 9.05 with a similar median value. The Eindex has average and median values around 2, which is not surprising given that the maximum value is 6 . Our sample firms have average book leverage to asset (Debt) ratio of $25.8 \%$, with median ratios of $23.5 \%$. The average firm has a research and development expense to asset $(R \& D)$ ratio of $2.4 \%$, with the median firm having no research and development expenses. On average, our sample firms have a natural logarithm of sales (Lsales) of 7.14, although there are many firms which are extremely large. The average size of our firms is \$4.3B, with a median value \$1.14B. 
Table I: Summary Statistics

\begin{tabular}{|l|l|l|l|}
\hline Variable & Mean & Median & Standard deviation \\
\hline Tobin's $Q$ & 1.004 & 0.674 & 1.064 \\
\hline Gindex & 9.044 & 9 & 2.749 \\
\hline Eindex & 2.295 & 2 & 1.335 \\
\hline Debt & 0.258 & 0.235 & 0.422 \\
\hline R\&D & 0.024 & 0 & 0.076 \\
\hline RDdum & 0.544 & 1 & 0.498 \\
\hline Lsales & 7.140 & 7.044 & 1.525 \\
\hline Lsales2 & 53.30 & 49.62 & 22.07 \\
& & & \\
\hline
\end{tabular}

E. Tests and Results - Full Sample

1. Fixed effects results. We begin by estimating a firm-level fixed effects regression of Tobin's Q on the two governance indices for the full sample period. It is the nature of fixed effect tests that they measure the effect on the dependent variable (in our case Tobin's Q) of a change in the independent variable (in our case the governance index). Hence this is the kind of test one would want to use to explore whether a change in an independent variable is a signal of some kind. The fixed effects technique also serves as a check on the conclusion from our cross-sectional OLS tests reported below (and those of Gompers et al.) ${ }^{103}$ that there is a relationship between firm good governance scores and high Tobin's Q. As discussed, using the fixed effects technique tests whether this OLS conclusion is a false positive arising from a hidden variable that correlates with

${ }^{103}$ Gompers et al., supra note 12. 
both Tobin's Q and the governance scores, but that is invariant over time. Our finding of a fixed effects relationship between Tobin's $\mathrm{Q}$ and the governance indices allows us to reject this alternative explanation of the OLS results.

Table II presents our fixed effects results for both the Gindex and the entrenchment Eindex. All standard errors are adjusted for clustering at the firm level, and the fixed-effects are jointly statistically significant but not presented. The robust t-statistics are presented in parentheses.

The impact of a change in the Gindex on Tobin's Q is given in column 2. We find a coefficient of -0.0259 , which is statistically significant at the one-percent level. The impact of a change in the Eindex is given in column 3 . We find a coefficient of -0.0384 on the Eindex which is statistically significant at the one-percent level. This is very similar to the Bebchuk et. al (2008) coefficient of -0.028 in their fixed effects regressions, although the respective sample periods differ slightly (ours is 1992-2006, and theirs is 1990-2003). Table III's results are consistent with those of the previous literature. This suggests that there is nothing unique about our sample that is generating our subsequent results.

In examining the relationship between the control variables and firm performance, Table II also shows that firms with higher debt levels and research and development expenses are associated with higher firm value. The relationship between firm size and performance is nonmonotonic, with a positive relationship that turns negative at the highest levels of firm size. 


\section{Table II: Fixed-Effects Regressions of Tobin's Q on} Corporate Governance Indices

\begin{tabular}{|l|l|l|}
\hline Variable & G index & E index \\
\hline Governance indices & $-0.0259^{* * *}$ & $-0.0384^{* * *}$ \\
& $(-3.05)$ & $(-2.65)$ \\
\hline Debt & $0.321^{* * *}$ & $0.318^{* * * *}$ \\
& $(4.92)$ & $(4.93)$ \\
\hline$R \& D$ & $0.596^{* *}$ & $0.597^{* *}$ \\
& $(2.15)$ & $(2.15)$ \\
\hline RDdum & 0.051 & 0.050 \\
& $(0.99)$ & $(0.98)$ \\
\hline Lsales & $0.108^{*}$ & $0.103^{*}$ \\
& $(1.87)$ & $(1.80)$ \\
\hline Lsales2 & $-0.010^{* *}$ & $-0.009^{* *}$ \\
& $(-2.23)$ & $(-2.19)$ \\
\hline
\end{tabular}

*** statistically significant at the $1 \%$ level, ** statistically significant at the $5 \%$ level, and * statistically significant at the $10 \%$ level, respectively.

2. Cross-sectional OLS results. In this section, we provide cross-sectional OLS results with 10 Fama-French industry controls and year dummies (not reported) and with standard errors clustered at the firm-level. ${ }^{104}$ For each variable, we calculate the average across the years by firm. By doing so, we abstract away from any time variation and focus on the cross-sectional variation only. ${ }^{105}$ These results, consistent with Gompers et al., ${ }^{106}$ show that both Gindex and Eindex are negatively correlated to firm Tobin's Q, i.e., the governance scores suggest that good corporate governance structures are associated with greater firm value creation.

\footnotetext{
${ }^{104}$ Note that a firm level fixed-effects model subsumes any impact of industry and therefore no industry controls need to be included.

${ }^{105}$ See William GreEne, ECONOMETRIC ANALYsis ( $7^{\text {th }}$ ed. 2005).

${ }^{106}$ Gompers et al., supra note 12 .
} 
Table III presents these OLS results for both the Gindex) and the entrenchment index Eindex. The robust t-statistics are presented in parentheses.

Table III: OLS Regressions of Tobin's Q on Corporate Governance Indices

\begin{tabular}{|l|l|l|}
\hline Variable & G index & E index \\
\hline Governance indices & $-0.0240^{* * *}$ & $-0.0661^{* * *}$ \\
& $(-4.21)$ & $(-5.45)$ \\
\hline Debt & $0.178^{* * *}$ & $0.184^{* * * *}$ \\
& $(3.46)$ & $(3.46)$ \\
\hline$R \& D$ & $3.18^{* *}$ & $3.158^{* * *}$ \\
& $(2.15)$ & $(2.83)$ \\
\hline RDdum & $-0.231^{* * *}$ & $-0.235^{* * *}$ \\
& $(-4.44)$ & $(-4.49)$ \\
\hline Lsales & $0.156^{*}$ & $0.167^{*}$ \\
& $(1.81)$ & $(1.94)$ \\
\hline Lsales2 & -0.008 & $-0.010^{* *}$ \\
& $(-1.47)$ & $(-1.69)$ \\
\hline
\end{tabular}

*** statistically significant at the $1 \%$ level, ** statistically significant at the $5 \%$ level, and * statistically significant at the $10 \%$ level, respectively.

The impact of a difference between firms in their respective Gindex scores on their Tobin's Qs is given in column 2 of Table III. We find a coefficient of -0.024 which is statistically significant at the one-percent level. The impact of a change in the Eindex is given in column 3. We find a coefficient of -0.061 on the Eindex which is statistically significant at the one-percent level. Our Gindex results are similar to the Gompers et. al ${ }^{107}$ coefficient of -0.043 in their OLS regressions. Again, while our sample periods differ slightly, the similarity in results suggests that there is nothing unusual about our sample that is generating our subsequent results.

${ }^{107}$ Gompers et al., supra note 12. 
3. Summary of the full sample results. Our full sample OLS results suggest that governance structures associated with good ratings, by filtering out bad managers and/or providing more effective managerial incentives, are consistent with better corporate decision making and hence, over time, higher cash flows available for shareholders. Our full sample fixed effects results share that consistency. They indicate that the OLS results do not represent a false positive caused by some hidden, time invariant variable that correlates with both a firm Tobin's Q scores and firm governance scores.

These full sample results, taken by themselves, do not, however, tell us whether a firm's decision to change its structure in a score-improving way constitutes a signal to the market concerning the quality of management. Assuming, as our OLS results suggest, that governance structures with better scores do in fact lead to higher cash flows to shareholders, we would see the fixed effects results that we have obtained even if the market were already fully informed about the quality of a firm's management prior to the change. In such a situation, there would be no need to signal management quality. Still, when a firm changes its structure in a score-improving way, the anticipation of the resultant better decision-making and increased future cash flows would, in an efficient market, lead to an immediate increase in share price. Thus, even without any signaling, our data suggests that the change in a firm's structure would still lead to a change in its Tobin's Q.

F. Results - Comparing 2001-2002 Scandal Years to the Other Sample Years

In reality, of course, the market is never fully informed about the quality of a firm's management. Suppose as well that in particular years the market believes that it is more poorly informed about firm management quality than in normal years. Further suppose, however, that the market's perception of the long run effect of a good governance structure on future cash flows 
(through better filtering out of bad managers and/or better incentives for all managers) does not change much from one year to the next. Under these assumptions, we would expect that if a scoreimproving change in governance structure serves as a signal concerning the quality of management, the signal would convey more information in years when the market perceives itself to be otherwise less informed about managerial quality.

Our hypothesis, therefore, is that if changes in governance structure constitute a signal concerning the quality of management, a fixed effects test will reveal that they have a bigger effect on Tobin's Q in years when the market perceives itself to be less informed concerning management quality relative to the governance effects on Tobin's Q in normal years. OLS tests that show no larger effect of governance on Tobin's Q in the less informed years than in normal years would show that such fixed effects results for the less informed years are not the result of the market believing in such years that a change in governance structure will have a bigger long run effect on future cash flows.

For the reasons discussed earlier, we believe that 2001-2002 scandal years was a period when the market perceived itself to be less informed concerning the quality of firm management than in normal times. Thus, to test our hypothesis concerning the signaling effect of changes in governance structure, we compare the fixed effects and OLS results for 2001-2002 with their respective results for the other years in our sample.

1. Fixed effects results comparison. The first step in the test is to split our full sample into two periods: the 2001-2002 accounting scandal period and the thirteen years surrounding that period (1990-2000 and 2003-2006). We repeat the same firm-level fixed effects regression 
specifications used for the full sample for each of these two periods. These results are given in Table IV.

The impact of the Gindex on firm performance in the accounting scandal period is shown in column 2. We find a coefficient of -0.0995 , which is more than three times as large as the normal times coefficient of -0.0291 given in column 3. Both coefficients are statistically significant at the one-percent level. When we compare the differential impact between scandal and normal years in column 4 , we find a negative effect of -0.0704 , which is also statistically significant at the one-percent level. In other words, we can say with a very high degree of statistical confidence that mere chance was not responsible for this observed difference between 2001-2002 and the surrounding thirteen years in the impact on Tobin's Q of from a firm changing its governance structure.

We then examine a similar relationship for the Eindex. Column 5 addresses the accounting scandal period. We find a coefficient of -0.0995 , which is again more than three times the normal year's coefficient of -0.0291 given in column 6 . Both coefficients are again statistically significant at the one-percent level. When we compare the differential impact between accounting scandal and normal years in column 4, we find a negative effect of -0.0704 , again statistically significant at the one-percent level.

To put these numbers in perspective in terms of their economic significance, Gompers et al.'s characterize firms with a Gindex greater than or equal to 14 as forming a "dictatorship portfolio" and ones with a Gindex of less than or equal to 5 as forming a "democracy portfolio."108

\footnotetext{
${ }^{108}$ Gompers et al., supra note 12.
} 
In governance terms, the Gindex difference between the worst democracy firm and the best dictatorship firm is 9. Now we calculate the difference in the impact on Tobin's $Q$ of a nine point drop in usual normal times and compare to an indentical drop in the accounting scandal period. The Tobin's $\mathrm{Q}$ of the median firm is 0.675 . Thus we can approximate the percentage impact of the nine point increase in normal times on the Tobin's $Q$ of such a firm as $(.0291 * 9) / 0.675=$ 38.8\%. In contrast, the approximate percentage negative impact on Tobin's $Q$ of the nine point index increase in the accounting scandal period is much larger: $(.0995 * 9) / 0.675=132.67 \%$.

If instead of assuming a favorable nine-point drop in the Gindex, we examine the impact of an unfavorable increase from the first quartile value of seven to the third quartile value of 11 , the percentage negative impact on Tobin's $Q$ in the accounting scandal period is still much larger $((.0995 * 4) / 0.675=132.67 \%)$ when compared to normal times $((.0291 * 4) / 0.675=17.24 \%)$.

Next we examine the economic significance of the Eindex by analyzing the impact on Tobin's Q of a favorable movement from the third quartile of the Eindex (equal to three) to the first quartile (equal to one), an increase of two. We calculate the difference in the impact on Tobin's Q of this two-point increase in normal times and compare it to making the jump in accounting scandal times. We can approximate the percentage negative impact on Tobin's Q of the two point decrease in normal times as $(.0462 * 2) / 0.675=13.7 \% \%$. Once again, the approximate percentage negative impact on Tobin's $Q$ of the two point drop in accounting scandal times is much larger: $(.1049 * 2) / 0.675=31.1 \%$. 
Table IV: Fixed-Effects Regressions of Tobin's Q on Corporate Governance Provisions For Governance Scandal Period v. Other Times

\begin{tabular}{|c|c|c|c|c|c|c|}
\hline \multirow[b]{2}{*}{ Variable } & \multicolumn{3}{|l|}{ Gindex } & \multicolumn{3}{|l|}{ Eindex } \\
\hline & $\begin{array}{l}2001-2002 \\
\text { Accounting } \\
\text { scandal }\end{array}$ & Other times & $\begin{array}{l}\text { Accounting } \\
\text { scandal - } \\
\text { other times }\end{array}$ & $\begin{array}{l}2001-2002 \\
\text { Accounting } \\
\text { scandal }\end{array}$ & Other times & $\begin{array}{l}\text { Accounting } \\
\text { scandal - } \\
\text { other times }\end{array}$ \\
\hline $\begin{array}{l}\text { Gindex/ } \\
\text { Eindex }\end{array}$ & $\begin{array}{l}-0.0995^{* *} \\
(-3.78)\end{array}$ & $\begin{array}{l}-0.0291 \text { *** } \\
(-3.22)\end{array}$ & $\begin{array}{l}-0.0704^{* * *} \\
(-2.53)\end{array}$ & $\begin{array}{l}-0.1049 \\
(-4.19)\end{array}$ & $\begin{array}{l}-0.0462^{* * *} \\
(-2.96)\end{array}$ & $\begin{array}{l}-0.0587 * * \\
(-2.03)\end{array}$ \\
\hline Debt & $\begin{array}{l}0.793 * * \\
(2.01)\end{array}$ & $\begin{array}{l}0.271 * * * \\
(5.10)\end{array}$ & & $\begin{array}{l}0.793 * * \\
(2.01)\end{array}$ & $\begin{array}{l}0.267 * * * \\
(5.09)\end{array}$ & \\
\hline$R \& D$ & $\begin{array}{l}1.352 \\
(0.44)\end{array}$ & $\begin{array}{l}0.613^{* *} \\
(2.10)\end{array}$ & & $\begin{array}{l}1.357 \\
(0.44)\end{array}$ & $\begin{array}{l}0.613 \\
(2.10)\end{array}$ & \\
\hline RDdum & $\begin{array}{l}-0.074 \\
(-0.53)\end{array}$ & $\begin{array}{l}0.058 \\
(1.06\end{array}$ & & $\begin{array}{l}-0.076 \\
(-0.54)\end{array}$ & $\begin{array}{l}0.058 \\
(0.95)\end{array}$ & \\
\hline Lsales & $\begin{array}{l}0.144 \\
(1.33)\end{array}$ & $\begin{array}{l}0.072 \\
(1.03)\end{array}$ & & $\begin{array}{l}0.144 \\
(1.33)\end{array}$ & $\begin{array}{l}0.066 \\
(0.95)\end{array}$ & \\
\hline Lsales2 & $\begin{array}{l}-0.020^{* * *} \\
(-2.61)\end{array}$ & $\begin{array}{l}-0.007 \\
(-1.37)\end{array}$ & & $\begin{array}{l}-0.020 * * * \\
(-2.61)\end{array}$ & $\begin{array}{l}-0.007 \\
(-1.32)\end{array}$ & \\
\hline
\end{tabular}

*** statistically significant at the $1 \%$ level, $* *$ statistically significant at the $5 \%$ level, and $*$ statistically significant at the $10 \%$ level, respectively.

2. OLS results. In this section, we provide cross-sectional OLS results comparing the 20012002 accounting scandal period with the years in our sample that surround it. Again, we calculate for each variable the average across the years by firm and thus abstract away from any time variation and focus on the cross-sectional variation only. The results in Table V show that both Gindex and Eindex scores are negatively correlated to firm performance in both the 2001-2002 accounting scandal years and in the normal years in our sample, but there is no statistically significant difference between the relationship in each of the two periods. 
Table V: Cross-Sectional OLS Regressions of Tobin's Q on Corporate Governance Provisions for Scandal and Other Times

\begin{tabular}{|c|c|c|c|c|c|c|}
\hline \multirow[b]{2}{*}{ Variable } & \multicolumn{3}{|l|}{ Gindex } & \multicolumn{3}{|l|}{ Eindex } \\
\hline & Scandal & Other & $\begin{array}{l}\text { Scandal- } \\
\text { Other }\end{array}$ & Scandal & Other & $\begin{array}{l}\text { Scandal } \\
\text {-Other }\end{array}$ \\
\hline $\begin{array}{l}\text { Gindex or } \\
\text { Eindex }\end{array}$ & $\begin{array}{l}-0.0183 * * \\
(-2.28)\end{array}$ & $\begin{array}{l}-0.0237 * * * \\
(-4.09)\end{array}$ & $\begin{array}{l}0.005 \\
(0.55)\end{array}$ & $\begin{array}{l}-0.059 * * * \\
(-3.78)\end{array}$ & $\begin{array}{l}-0.0633 \text { *** } \\
(-5.15)\end{array}$ & $\begin{array}{l}0.004 \\
(0.21)\end{array}$ \\
\hline Debt & $\begin{array}{l}0.580^{* * * *} \\
(3.94)\end{array}$ & \begin{tabular}{|l}
$0.244 * * *$ \\
$(3.07)$
\end{tabular} & & $\begin{array}{l}0.587 * * * \\
(4.01)\end{array}$ & $\begin{array}{l}0.254^{* * * *} \\
(3.21)\end{array}$ & \\
\hline$R \& D$ & $\begin{array}{l}2.78^{* * * *} \\
(4.40)\end{array}$ & \begin{tabular}{|l}
$2.85 * *$ \\
$(2.52)$
\end{tabular} & & $\begin{array}{l}2.76^{* * * *} \\
(4.33)\end{array}$ & $\begin{array}{l}2.83^{* *} \\
(2.49)\end{array}$ & \\
\hline RDdum & $\begin{array}{l}-0.191 * * * \\
(-3.65)\end{array}$ & \begin{tabular}{|l}
$-0.200 * * *$ \\
$(-3.95)$
\end{tabular} & & $\begin{array}{l}-0.196 * * * \\
(-3.72)\end{array}$ & \begin{tabular}{|l}
$-0.204 * * *$ \\
$(-4.01)$
\end{tabular} & \\
\hline Lsales & $\begin{array}{l}-0.286^{* *} \\
(-2.50)\end{array}$ & \begin{tabular}{|l|}
0.129 \\
$(1.46)$
\end{tabular} & & $\begin{array}{l}-0.297 * * * \\
(-2.60)\end{array}$ & \begin{tabular}{|l|}
0.138 \\
$(1.56)$
\end{tabular} & \\
\hline Lsales & $\begin{array}{l}-0.015^{*} \\
(-1.95)\end{array}$ & $\begin{array}{l}-0.007 \\
(-1.16)\end{array}$ & & $\begin{array}{l}-0.016^{* *} \\
(-1.95)\end{array}$ & $\begin{array}{l}-0.008 \\
(-1.36)\end{array}$ & \\
\hline
\end{tabular}

*** statistically significant at the $1 \%$ level, $* *$ statistically significant at the $5 \%$ level, and $*$ statistically significant at the $10 \%$ level, respectively.

3. Summary of results in accounting scandal years versus other years. The results reported above provide strong support our hypothesis that that changes in governance structure in particular contexts can constitute a credible signal concerning the quality of management. As our hypothesis would predict, our fixed effects tests reveal that score-improving changes in corporate governance have a highly statistically significant larger effect on Tobin's Q in the accounting scandal period 2001-2002, years when the market appeared to perceive itself as less informed than during the normal twelve year surrounding period. Our OLS tests reveal no statistically different effect of governance structure differences across firms on Tobin's Q in 2001-2002 than in other years. 
These latter results suggest that our fixed effects results do not arise because, in the accounting scandal years, the market believes the long run effect of governance changes on future cash flows will be greater because of their filtering or incentive effects.

\section{G. Focussing on Staggered Boards and Poison Pills}

Most commentators believe that the most important governance-structure determinants of a poorly managed firm to takeover are the presence or absence of a poison pill and a staggered board, two of the 24 elements going into the $\mathrm{G}$ index and two of the six elements going into the E index. ${ }^{109}$ We examine the change in Tobin's Q during the scandal years of 2001-2002 versus the effect of a change during the other years in our sample. The results in Table VI show that, in each case, the effect was greater in the 2001-2002 period by an amount that was statistically significant at the $1 \%$ level. In other words, again we find a larger impact from changes in governance structures in a period of greater uncertainty as to management quality. These findings reinforce our conclusion that certain governance structure changes can serve as a signal of management quality.

Table VI: Changes in Tobin's $Q$ when Firm Initiated a Staggered Board or a Poison Pill for Scandal Period and Other Times

\begin{tabular}{|l|l|l|l|l|}
\hline & & Scandal & Other & Scandal-other \\
\hline \multirow{3}{*}{ Initiated staggered board } & Mean & -0.168 & -0.053 & $-0.115^{* * *}$ \\
& (t-statistic) & $(-1.93)^{*}$ & $(-0.84)$ & \\
\hline \multirow{3}{*}{ Initiated poison pill } & number & 27 & 93 & $-0.169^{* * *}$ \\
& Mean & -0.257 & -0.089 & \\
& (t-statistic) & $(4.46)^{* * *}$ & $(-1.79)^{*}$ & \\
& number & 88 & 369 & \\
\hline
\end{tabular}

*** statistically significant at the $1 \%$ level, $* *$ statistically significant at the $5 \%$ level, and $*$ statistically significant at the $10 \%$ level, respectively.

\footnotetext{
${ }^{109}$ See, e.g., note 17 supra.
} 


\section{H. Firms Where the Asymmetry of Information with the Market is Greater}

The above results show that changes in a firm's governance structures in the accounting scandal years had a larger effect on their Tobin's Qs than changes made in normal years. We interpret this result as showing that in identifiable contexts, changes in governance structure can have a signaling effect concerning managerial quality: if governance changes are signals of managerial quality, we would expect a bigger impact on firm value when the market is less informed. This is what our results show.

The robustness of our explanation is bolstered by some additional findings. If our explanation is correct, then we would also expect that when firms that are less well understood by the market change their governance structures, the impact of the change on their Tobin's Q in the accounting scandal years would be even greater than for other firms that changed their governance structures in those years. Firms that spend money on research and development $(\mathrm{R} \& \mathrm{D})$ are more opaque on average than those that do not because in general it is much harder to assess how worthwhile these expenditures are than are expenditures for tangible physical assets. In essence, there is on average a greater asymmetry of information between managers and the market in the case of R\&D firms.

To test this hypothesis, we split our sample into firms with R\&D expenditures and those with no such expenditures. We repeat our fixed effects regressions of Table V, but for ease of exposition present in Table VII only the results on the governance indices. Firms that change their governance structures and do have $R \& D$ expenditures - those for whom there is a greater information asymmetry between managers and the market - have a greater increase in Tobin's Q during the accounting scandal period than do firms that change governance structures but have no 
R\&D spending. These results provide further support for our signaling hypothesis because we see again that the less informed the market, this time across firms, the bigger the effect of a governance change on Tobin's Q.

Table VII: Fixed-Effects Regressions of Tobin's $Q$ on Corporate Governance Provisions for Firms with and without R\&D in the Scandal and Other Times

\begin{tabular}{|l|l|l|l|l|l|l|l|}
\hline \multirow{2}{*}{ Variable } & \multicolumn{2}{|l|}{ With R\&D } & \multicolumn{3}{l|}{ Without R\&D } & $\begin{array}{l}\text { Difference } \\
\text { with and } \\
\text { without } \\
\text { R\&D }\end{array}$ \\
\cline { 2 - 8 } & Scandal & Other & $\begin{array}{l}\text { Scandal- } \\
\text { Other }\end{array}$ & Scandal & Other & $\begin{array}{l}\text { Scandal- } \\
\text { Other }\end{array}$ & \\
\hline Gindex & $-0.127^{* * *}$ & $-0.032^{* * *}$ & $-0.094^{* * *}$ & $-0.052^{* * * *}$ & -0.011 & $-0.041^{* * * *}$ & $-0.054^{* * *}$ \\
& $(-4.05)$ & $(-1.96)$ & $(-2.67)$ & $(-5.04)$ & $(-1.57)$ & $(-3.25)$ & \\
\hline Eindex & $-0.180^{* * *}$ & $-0.051^{*}$ & $-0.129^{* *}$ & $-0.080^{* * * *}$ & -0.019 & $-0.060^{* * *}$ & $-0.069^{* * *}$ \\
& $(-3.96)$ & $(1.75)$ & $(-2.40)$ & $-3.47)$ & $(-1.42)$ & $(-2.58)$ & \\
\hline
\end{tabular}

*** statistically significant at the $1 \%$ level, ** statistically significant at the $5 \%$ level, and * statistically significant at the $10 \%$ level, respectively.

\section{Conclusion}

Prior scholarship reports a relationship between firms with good corporate governance index ratings and those best at creating shareholder value, results that our study confirms. However, little work explores why we observe this relationship. We hypothesize that, in the right context, a change of corporate governance structure that results in a changed rating can be a signal concerning the quality of a firm's management. This is because a change in governance structure that makes a firm's management more vulnerable to a hostile takeover, or that gives independent directors or activist shareholders more voice, imposes greater costs on poor quality managers than on good quality ones. A positive signal concerning the quality of management would lead to a 
positive reevaluation by the market of a firm's future cash flows and hence an increase in the firm's Tobin's Q.

We test this hypothesis by focusing on 2001-2002. This is the period of unprecedented corporate accounting scandals, such as Enron and WorldCom, involving the fall from grace of some of America's largest and most respected companies. Commentators reported concern about where the "next shoe would drop" and, more generally, reduced confidence in the accounting behind firms' reports of past performances. The market thus perceived there to be a greater asymmetry of information between it and corporate insiders concerning the quality of firm management. In such an environment, the signal of management quality arising from a change in governance structure would take on particular significance.

We compare results testing the relationship between firms' governance indices score and Tobin's Q in this 2001-2002 period with results from the same tests in the years surrounding the accounting scandal period (1992-2000 and 2003-2006). The comparison involves both the results from fixed effects tests of the impact of an index score-improving governance change in structure on Tobin's Q in any given year and the results of cross sectional OLS tests on the relationship in any given year between firm governance ratings and firm Tobin's Qs. The comparison of the fixed effects tests reveals that an improved governance index score in the accounting scandal years is associated with a much larger increase in Tobin's Q than a comparably sized rating improvement occurring in the surrounding years. This difference is highly significant both statistically and economically.

In contrast, the comparison of the OLS results shows no significant difference in terms of the relationship between a firm's governance index rating and its Tobin's Q during the accounting 
scandal period (2001-2002) and during the surrounding years. This difference between the fixed effects comparison and the OLS comparison strongly suggests that signaling was at work. The fact that the OLS finding for 2001-2002 is not significantly different from the OLS finding for these other years suggests that the market's perception of the filtering and incentive effects of a good corporate governance structure did not change during these two accounting scandal years.

Suppose that the market has complete information concerning the quality of each firm's management. In that event, there is no reason to think that a firm making a governance index rating improvement would, because of the anticipation of better decision-making and resultant increased future cash flows, enjoy any greater immediate price increase in the 2001-2002 accounting scandal period than would a firm making the same change in the surrounding years in our sample. Yet our fixed effects result shows that a firm making such a change in 2001-2002 secured a substantially greater immediate increase in price compared to making such a change in normal years. We conclude that the market must have learned something positive about management quality from the fact of the governance change. In other words, the governance change was a signal of management quality.

We strongly suspect that the signaling capacity of such a change was not confined to 20012002. The market also did not know everything about management in 1996-2000 and 2003-2006. Likely, what we are seeing in 2001-2002 is simply a larger than usual signaling effect because, in this period, the market was abnormally uncertain about the quality of management prior to receiving the signal across a wide swath of firms. Thus, in response to the question we posed at the outset - why the observed relationship between governance ratings and Tobin's Q and under 
what circumstances would governance structure particularly matter-we believe that signaling can play a substantial role in certain contexts.

The idea that governance structure choices can serve a signaling function is an important conclusion. Reducing asymmetry of information between the market and corporate insiders significantly enhances the efficiency of the economy. It allows improved monitoring of managers so that they are under more pressure to better utilize a firm's existing productive assets and to make better decisions concerning investments in new projects. The more accurate share prices that result from reduced asymmetries also help the efficiency with which capital is allocated by external capital markets and make trading markets more liquid. A variety of regulations are designed, at least in part, to reduce these asymmetries, including our mandatory issuer disclosure regime and the antifraud rules concerning trading on private information. In designing public policy, it is important to appreciate as well the role that the actions of private actors can play in reducing these asymmetries. Our results give new insight in this regard. They also suggest how sharply asymmetries about management quality can grow if regulatory and gatekeeper failures allow a substantial number of accounting frauds to develop. 